\title{
Bán Attila
}

\section{Katonaerkölcsi értékek érvényesülése a Kratochvil Károly Honvéd Középiskola és Kollégiumban végzett növendékek életében}

DOI 10.17047/HADTUD.2020.30.3.67

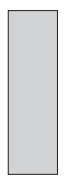

\begin{abstract}
A tanulmány a katonaerkölcsi értékek - a bajtársiasság, fegyelmezettség, a becsületesség - megjelenését, hasznosíthatóságát vizsgálja a Kratochvil Károly Honvéd Középiskola és Kollégiumban (KKHKK) 2015-2017 között érettségizett növendékek mindennapi életében. Elemzi a KKHKK-ban zajló katonai szocializációs nevelés sikerességét. KULCSSZAVAK: katonai középiskola, katonaetika, katonai nevelés, KKHKK
\end{abstract}

\section{A research on the military Code of Ethics considering the everyday lives of those graduated from Military High School KKHKK}

This paper is about examining the expedience of the military code of ethics. In the essay I analyze the existence of courage, discipline, honesty in the everyday lives of those graduated from KKHKK and I also analyze the success of military education at KKHKK.

KEYWORDS: military high school, military code of ethics, military education, KKHKK

\section{Elôszó}

Magyarországon 2004-ben, az önkéntes haderôre történô átállásnak köszönhetően a klasszikus sorkatonai szolgálat felfüggesztésre került. Ennek következményeként a honvédség bizonyos tekintetben háttérbe szorult a civil köztudatban. Egy ponton azonban még megmaradt a kapcsolat. Ez volt az úgynevezett katonai középiskolai rendszer, mely részint a serdülókorú fiatalok honvédelmi nevelését volt hivatott szolgálni, részint az utánpótlás lehetôségét biztosította a honvédség számára, hiszen a katonai szocializációs alapokat ezek az intézmények jellegükból adódóan magukban hordozták. A katonai középiskolák alternatívát nyújtottak a 14-18 éves korosztály

\footnotetext{
^ิ Kratochvil Károly Honvéd Középiskola és Kollégium - 'Kratochvil Károly' 'Honvéd' Secondary School and
} Dormitory; email: banattila.82@gmail.com; ORCID: 0000-0001-9184-1064 
részére, hogy megismerkedjenek a honvédség felépítésével, múködésével, és egyben kiváló lehetôséget adtak arra is, hogy a honvédelmi értékek, a hazafias nevelés és a katonai erkölcsi értékek átadása megvalósuljon.

Ilyen típusú közintézmények már az Osztrák-Magyar Monarchia idején is léteztek, de a tanulói létszámot tekintve a 20. század utolsó harmada nevezhetố a magyarországi katonai kollégiumok fénykorának. 1974-tól tizennyolc honvéd középiskolát hoztak létre az ország különböző pontján, jellemzően a megyeszékhelyeken.

A szervezeti átalakítások során a kilencvenes évek második felében az MH középiskolai rendszerét szinte teljesen felszámolták, 2007-ben Gyớrben az utolsó intézményt is bezárták. Így nem csupán a közvetlen kapcsolat szúnt meg a középiskolai korosztály és a honvédség között, hanem a köznevelésben is hiátus keletkezett a honvédelmi nevelés tekintetében. E hiány pótlására hozták létre 2013-ban a debreceni székhelyú Kratochvil Károly Honvéd Középiskola és Kollégiumot (továbbiakban: KKHKK) a katonai középiskolák mintája alapján, de jogállás szempontjából eltérô, új típusú középfokú közoktatási intézményként, amelyet a szaktárca a kezdetektól támogatott. ${ }^{1}$

A KKHKK egyfajta hibrid intézmény, mert megfelel a polgári közoktatási tanintézményekkel szemben támasztott követelményeknek, illetve ezzel párhuzamosan egy speciális, katonai jellegú szabályrendszert alkalmaz, amely szervesen kapcsolódik a honvédelmi neveléshez, és a katonai szocializáció elsô lépcsófokának, ha úgy tetszik elôszobájának tekinthetó

Vizsgálatom tárgya, hogy az említett intézményben 2015-2017 között érettségizett növendékek, foglalkozásuktól függetlenül, milyen mértékben képesek hasznosítani azon katonaerkölcsi ismereteiket, amelyekkel a KKHKK falai között találkoztak, vagy ugyanezen ismeretek esetlegesen mennyire gátolják óket a polgári életvitelükben.

\section{Katonaerkölcsi nevelés az intézményben}

A katonai közösségre jellemzó jogi szabályrendszer kialakít az egyénben egy olyan magatartási formát, amely kikerülhetetlenné teszi a szabálykövetést, vagyis a katona ráébred arra, hogy a szabályok bizonyos funkciókat tartalmaznak, amelyeknek rendeltetése van. Ez a funkciórendszer válik majd a katona számára szükségszerúvé ahhoz, hogy helyesen múködjön az adott rendszeren belül. ${ }^{2}$ Ki kell hangsúlyozni, hogy a honvéd középiskolában nem katonai nevelés, hanem az életkori sajátosságok figyelembevétele alapján honvédelmi, hazafias nevelés zajlik. Ennek keretében a KKHKK növendékei a közismereti és szakmai tantárgyak mellett megismerik és elsajátítják a katonai szempontból legfontosabb erényeket: a hazaszeretetet, kötelezettségérzetet, bajtársiasságot, engedelmességet és becsületességet.

Az erkölcsi nevelés mellett kiemelt fontosságú a fizikális képességek javítása, amely elősegíti a test egészséges fejlődését, és felkészíti a növendékeket - katonai pályaválasztás esetén - az alkalmassági vizsgálaton történô megfelelésre. ${ }^{3}$ Az intézményben

1 http://www.kratochvil.hu/index.php/iskolankrol (Letöltés ideje: 2019. 10. 14.)

2 Molnár Károly ezds.: A jog és az erkölcs viszonyáról. In: Katonaetika, tanulmánygyújtemény. Szerk. Molnár Károly. Budapest, Zrínyi Kiadó, 1993. 19-20. o.

3 A KKHKK Pedagógiai Programja, http://kratochvil.hu/index.php/dokumentumok (Letöltés ideje: 2019. 10. 14.) 
dolgozó katonapedagógusok ${ }^{4}$ jelenléte elôsegíti a honvédelmi nevelést, hiszen a növendék közvetlen kapcsolatba kerül a honvédség hivatásos vagy szerződéses állományú tagjával. A kollégiumban minden évfolyamhoz katonai nevelótanár van hozzárendelve, de a honvédelmi szaktantárgyakat is katonapedagógus tanítja. Egy adott évfolyamban felmenô rendszerben három osztály található meg. Az ", $\mathrm{A}$ ” gimnáziumi osztály, amely emelt óraszámban angol nyelv mellett francia nyelvet, illetve heti két órában elméleti honvédelmi alapismereteket és másik heti két órában gyakorlati honvédelmi alapismereteket tanul. A „B" szakgimnáziumi osztály elektronikai szakmai képzésben részesül, ${ }^{5}$ valamint heti két-két órában honvédelmi alapismereteket tanul. A "C" osztály egy új típusú, úgynevezett "kadét” honvéd ágazati képzést sajátít el. Számukra a honvédelmi alapismeretek tantárgy van további szaktantárgyakra lebontva, úgymint például a jogi ismeretek vagy a vezetés alapjai tantárgyak.

\section{Fố erények a honvédelmi nevelésben}

Bár a katonai etika szakmai etikának minősül, ezáltal egy speciális környezetre vonatkozik, de mint minden más etikai irányzat, az általános etika gyökeréból ered. Tehát, alapvetően felmerül az erkölcsi jó és rossz katonaetikai értelmezése. Ami egy katonának evidens a honvédség rendszerében, egy polgári személy számára logikátlan és értelmetlen cselekvésnek tûnhet. A civil közösség magyarázat és érvelési alapokon nyugvó berendezkedésével szemben a katonai környezet konzervatív és hagyományokon alapuló parancs-engedelmességi rendszer. A honvédelmi nevelésben a katonai erkölcsrendszer kicsinyített mását találjuk meg.

Az etikai oktatásnak köszönhetóen a tanulók már az általános iskolában megismerkednek a sarkalatos erényekkel. Az igazságosság, bölcsesség, mértékletesség és a bátorság, mint fó erények az erkölcsi jó megtestesítói, jelen vannak minden etikai irányzatban, így a katonai etikában is, tehát a fó erények a honvédelmi nevelésben is megjelennek.

Az igazságosság minden közösség alapja, közös elvek mentén történő egyetértés, írott és íratlan szabályrendszer. Érdekes, hogy a magyar nyelvben az igazságosság főnevet az igazság alapszóból képezzük, míg az angolszász területeken a jog, azaz a justitia szóból ered. Ergo, a törvény, a törvénykezés az igazságosság jogszerú, állami kereteken belüli megvalósítása, mindenki számára kötelezố érvényú szabályok összessége. Nem vitatkozhatunk a szókratészi gondolattal, vagyis az igazságosság az, ha mindenkinek megadjuk azt, ami neki jár. A honvédelmi nevelés szabályrendszere a katonai szabályok figyelembevételével van kialakítva. A kötött jogrendszer érvényesítésének egyik fó pillére a parancs. A parancs megkerülhetetlen, arra engedelmeskedni kell. De a parancsot sokkal könnyebb teljesíteni, ha azt a saját igazságérzet helyesnek tartja, azaz egy véleményem van az az elöljáróval. Elófordulhat, hogy a kapott paranccsal egyáltalán nem vagy csak részben értek egyet. Nem tartom

4 Felsófokú pedagógiai végzettséggel rendelkező és a Magyar Honvédségben szolgálati viszonyban lévô személy.

5 Az épületben egykor elektronikai tiszthelyettes képzés, majd polgári elektronikai középiskolai szakképzés folyt. Az infrastruktúra kiépítettsége miatt célszerú volt ezt a képzési formát megtartani. 
igazságosnak, akár büntetésként is felfogható. A serdülókor egyik sajátossága, hogy a kapott ingert képes az egyén egyfajta támadásként értelmezni, pedig ha elfogadná azt, az ó javára válna. Érzékeny életkor ez az identitásfejlődés szempontjából, emiatt a honvédelmi nevelés során a parancsot adó elöljárónak mindig elótérbe kell helyeznie, hogy a végrehajtó állomány nem felnốtt korban lévố személy. A parancs egy összetett, erkölcsi és szakmai döntésekból álló speciális irányítási forma, mely vezeti az emberi cselekvéseket, hasonlít az erkölcsi és morális tevékenységekhez. A „Mit kell tenni?" kérdésre ad választ, azaz megmondja mi a jó, a helyes, a becsületes stb... ${ }^{6}$ Erkölcsformáló hatása vitathatatlan, ezért minden esetben törekedni kell arra, hogy az adott parancs igazságos, ezáltal hiteles és megkérdójelezhetetlen legyen. Egy rosszul megfogalmazott parancs vagy szerencsétlen szituáció végérvényesen elfordíthatja a tanulót a honvédelmi értékektól, az esetleges késóbbi hivatásos szolgálattól, illetve problémát okozhat a személyiségfejlődésben is.

A katonai középiskolai rendszer megszületésekor Magyarországon a politikai viszonyok által meghatározott, kötött, szabálykövetô társadalmi berendezkedés létezett. Emiatt az akkori kor serdülókorú fiataljai számára magától értetődő volt az a hierarchikus rend, amelyet a katonai középiskolák képviseltek. A jelenkor fiatalságának nehezebb a helyzete, ha a honvédelmi képzésben képzelik el a jövőjüket. Napjaink társadalmi berendezkedése ugyanis sokkal liberálisabb rendszer, amely a tapasztalás, kreativitás és személyiségfejlődés szempontjából előny, viszont egy kötött formájú rend megtanulása szempontjából hátrány lehet. További hátrányt jelent, hogy napjaink társadalma nem fordít kellő figyelmet az alapvetố értékek, ezáltal a sarkalatos erények alaposabb megismerésére, megkövetelésére sem, jóllehet az elmúlt néhány évben mind az általános, mind a középiskolákban helyet kapott az erkölcstan és etika oktatása.

A honvéd középiskolában a növendékek első naptól kezdve találkoznak a sarkalatos erényekkel, és emellett természetesen a speciális, katonaerkölcsi értékekkel is. Az iskolában eltöltött négy év során mindennapi tevékenységükbe és létformájukba beleépül a bátorság és a becsületesség, a méltányosság és a bajtársiasság. Joggal merül fel a kérdés, miért nem választja mindenki a katonai pályát? Az iskolának célja, hogy minél több gyerek katonai hivatást válasszon, de nem kívánjuk ráeróltetni a pályát a fiatalokra. A honvédelmi nevelés nem csupán pályára irányítást jelent, hanem a társadalom számára olyan fiatal felnóttek nevelése a cél, akik befogadók és megértóek a honvédelemmel, a haza védelmének szükségességével kapcsolatban. Ehhez elengedhetetlen egy egészséges formájú erényismeret, és elóny a katonaerkölcsi ismeret. A szabályok betartásának megkövetelése, a napirend betartása a honvéd középiskolában mindennapi rutinnak számít. A napirend egy fix támpont, melyre mindenki támaszkodik, hivatkozik. A napirend nevelési jelentôsége megkérdôjelezhetetlen. A diák rendet, rendszert tanul meg, mely felnótt korában rendszerességet, pontosságot, toleranciát jelenthet. Vizsgálódásom témája pontosan ez. Mennyire képes hasznosítani a középiskolában megszerzett erkölcsi, katonaerkölcsi ismereteit a volt növendék, legyen szó katonai pályát vagy civil életet választott egyénról.

6 Boda Mihály: A katonai vezetés erkölcsi és morális elemei. Hadtudomány, 25. (2015), E-szám. 


\section{A végzett növendékek pályaválasztása, a vizsgálati anyagok elemzése}

A KKHKK elődintézménye, a Gábor Dénes Elektronikai és Múszaki Szakközépiskola 12. évfolyamos diákjai 2013-ban az intézmény átalakításának évében választhatták a honvédelmi nevelést. Így 2014 júliusában végzett az elsố honvédelmi képzést kapott évfolyam, igaz, ók még nem kötelezóen kollégiumi bentlakással és egyenruha nélkül, ${ }^{7}$ civil öltözetben voltak, illetve a katonai alapismeretek tantárgyból való érettségi ${ }^{8}$ sem volt kötelezô számukra. De a katonai alapértékekkel már ók is találkoztak. Hibás, vagy legalábbis nem valós értékú eredmény lenne, ha már az elsô végzett évfolyamot vizsgálatom tárgyává tenném, hiszen a mai intézményi rend már egyáltalán nem hasonlít a kezdeti idôszakra. Bár hozzá kell tennem, hogy már az elsố végzett évfolyamból vállaltak katonai pályát néhányan. Pedig akkor még az előd intézmény milióje dominált a KKHKK falain belül.

Reálisabb eredményt vártam tehát, ha vizsgálatom tárgyát a 2015-2017 között végzett növendékek megkérdezésével próbálom megvalósítani. Ugyanis ók már elég idốt töltöttek az iskolában ahhoz, hogy a katonai jellegú nevelés hatással legyen a személyiségükre, illetve az érettségi után megfeleló idő telt el ahhoz, hogy el tudják dönteni azt, hogy a honvédelmi nevelés hogyan befolyásolta, befolyásolja jelenlegi életüket. Szándékom volt, hogy a megkérdezett növendékek aránya egyenló legyen abban a tekintetben, hogy katonai vagy civil pályát választottak. A megkérdezett fiatalok a felkérésemre kényszer nélkül, és örömmel jelentkeztek. Összesen 26 fiatalt kérdeztem meg online, skype illetve messenger chat interjú keretében 2019. december 06. és 2020. január 19. között. A 26 fő kevésnek tứnhet, de az intézményben lévő, viszonylag kis létszámú osztályokra levetítve ez évfolyamonként nagyjából 30\%-os arányt jelent. Mindenkinek ugyanazt a hat kérdést tettem fel, függetlenül attól, hogy milyen pályára lépett. Felhívtam az interjúk elótt az alanyok figyelmét, hogy a kérdésekre ốszintén válaszoljanak, még akkor is, ha az esetlegesen negatívan hathat a vizsgálat eredményére. Biztosítottam óket arról, hogy személyazonosságukat sem harmadik félnek, sem a vizsgálat leíró anyagában nem adom át, nem adom ki.

Az interjú során feltett kérdések:

1. Milyen okból választotta ezt az iskolát?

2. Mivel foglalkozik jelenleg?

3. Milyen pozitív és negatív tapasztalata van az iskolában kapott honvédelmi nevelésról?

4. Segíti-e a mindennapi életben (munka, család, barátok stb.) a kapott katonai jellegú nevelés?

5. Hátráltatja-e a mindennapi életben (munka, család, barátok stb.) a kapott katonai jellegú nevelés?

6. Tud mondani 3 olyan erényt, amelyek ön számára a katonaerkölcsöt testesítik meg?

7 A növendékek ünnepi egyenruhával (formaruhával) rendelkeztek, de a mindennapi iskolai életben civil öltözetben voltak.

8 A katonai alapismeretek tantárgyból a 2019/2020. tanévtól kezdődóen kötelezően érettségi vizsgát kell tenni minden növendéknek. 
A kérdéseket szándékosan úgy állítottam össze, hogy azokból egyértelmúen kiderüljön az interjúalany véleménye a honvédelmi nevelésról, kétértelmúség ne legyen feltételezhetô. A vizsgálat könnyebb értelmezhetősége és összesíthetősége érdekében kérdéseként elemzem a megadott válaszokat, melyeket egyes esetekben diagramon, más kérdések esetében az interjú alanyok által megfogalmazott idézetekkel prezentálok.

Az elsô kérdésben arra voltam kíváncsi, hogy mi motivál egy 8. osztályos tanulót arra, hogy a honvéd középiskolában tanuljon tovább. A válaszok alapján két, jól elkülöníthetố kategóriára osztható a megkérdezett volt diákállomány. Az első kategória, amelybe azok tartoznak, akik már a profilváltás (fenntartóváltás) elótt ebben az intézményben tanultak, a második kategória pedig az, akik már a HKK-ba felvételiztek. Az elsố kategóriába tartozók (12 fô) válaszai egymástól függetlenül szinte ugyanazok voltak. Az iskolában folyó magas szintú elektronikai képzés, illetve a jól kialakult osztályközösség miatt nem szerettek volna iskolát váltani:

„Nekem a fó szempontom az elektronikai irány volt, mivel általános iskolában fizikán azt szerettem a legjobban, és sok jót hallottam az iskoláról, így oda jelentkeztem."

"A váltás után azért maradtam az iskolában, mert jó osztályközösség volt. Azt hiszem, másodikos voltam akkor."

"Most ôszinte leszek, egyedül az osztályközösség tartott abban az iskolában."

A második kategóriába tartozók (14 fố) közül 50\% filmek és számítógépes játékok alapján (semmilyen kapcsolat nem volt a honvédséggel, de a médiában néha látott katonát), 30\% elbeszélések, filmek, számítógépes játékok alapján (szüló, rokon katona, médiakapcsolat), 20\% szaklapok, média, alakulatlátogatás, elbeszélések stb. alapján (folyamatos kapcsolat a honvédséggel) döntött az iskolában történó továbbtanulásáról.

"Az iskolát azért választottam, mert hallottam, hogy katonai nevelésben részesülnek a diákok, meg hogy katonasuli programos volt, és megkönnyíti a katonai pályán való elhelyezkedést."

"Mindig is érdekelt a történelem, a honvédelem, azon belül a hadsereg, illetve a fegyverzetek."

A két kategória bár teljesen különbözik, azonban a választás tekintetében egy dologban mégis egyezik. Mindkét csoport tagjai megerősítették, hogy a döntésüket befolyásolta a katonákról elképzelt pozitív sztereotípia, vagyis a katona a gyerek számára az erkölcsi magatartás mintapéldája.

A második kérdésben kiderült, hogy az interjúalany milyen pályát választott. Ezt tulajdonképpen már a beszélgetés elótt tudtam, de a részletesség érdekében, illetve az alany távlati terveinek vonatkozásában semmiképpen sem elhanyagolható kérdés. Ahogy már említettem, az alanyok között a katonai vagy civil pályát választók aránya 50-50\% volt. Akik katonai pályára mentek, azok közül 3-an tiszti, 6-an altiszti hivatást, míg 4-en a szerződéses legénységi szolgálatot választották. A civil életet választók közül 4 fố főiskolai vagy egyetemi tanulmányokat folytat, 3 fő középfokú intézményben tanul, 6 fő a technikus képzést követôen munkát vállalt civil cégeknél. A diagram érdekessége (1. ábra), hogy a megkérdezettek között legalább annyira népszerú alternatívát jelent az altiszti pálya, mint a civil szférában történố munkavállalás, valamint az altisztképzésben részt vevő volt növendékek aránya duplája azoknak, akik civil középfokú intézményben folytatták tanulmányaikat.

A harmadik kérdés nem csupán az erkölcsi értékek megtanulási folyamatára, annak könnyedségére vagy nehézségeire irányult, hanem arra is, hogy a diákokban 


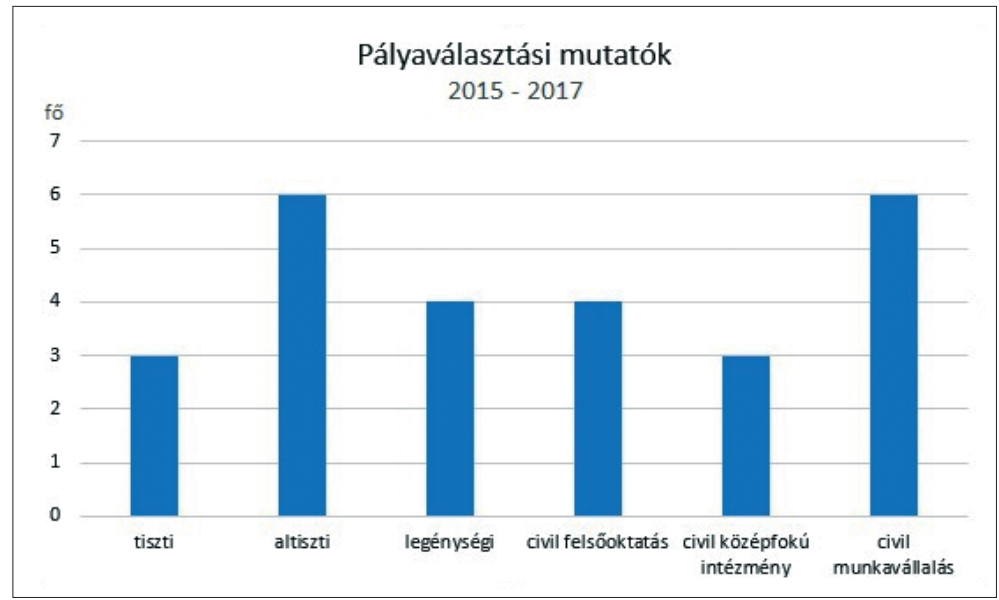

1. ábra.

Pályaválasztási mutatók

(A diagram a szerző saját alkotása)

milyen személyes-érzelmi stabilitást vagy akár instabilitást hoztak az intézményben átélt szituációk. Kivétel nélkül minden alany szóbahozott valamilyen erényt. Az általánosnak, már-már közhelyesnek túnó bátorság és bajtársiasság mellett a magabiztosságot, a mértékletességet és elfogadást is említették. Emellett kiemelték a rend megtanulásának folyamatát, melyet jelenleg is hasznosítanak az életükben, de szóba került az is, hogy az intézményi nevelésnek köszönhetóen hivatalos szituációkban is megállják a helyüket.

A teljességhez hozzátartozik a negatív tapasztalatok megvizsgálása is. Az iskolában töltött évek alatt a növendékek pályaválasztási képe megváltozhat, sót, sok esetben meg is változik. A gyerek idóközben rájön, hogy mégsem szeretné a katonai pályát választani, amihez teljességgel megvan a joga. A civil szférában elhelyezkedó válaszadók nagyjából 10\%-a szerint érezhetó volt, hogy akik nem választanak katonai pályát, azokat diszkriminálják. Viszont ezen válaszadók azt is elismerték, hogy bár ók maguk nem tudtak azonosulni a honvédséggel, de bizonyos katonai értékeket elfogadnak és tiszteletben tartanak. Más válaszadók azt rótták fel, hogy amíg a kezdeti idókben (2013) a szigor és fegyelem megkérdójelezhetetlen volt, ahogy az iskola egyre nagyobb hírnevet szerzett, a meglévő fegyelem annál hiányosabbá vált.

A negyedik kérdésben arra kerestem a választ, hogy a végzett növendéket mennyire segíti a mindennapi életében a kapott nevelési forma, legyen szó civil vagy katonai életról. A válaszokban egyértelmú homológia mutatkozik. Minden alany megemlítette a rendtartást, az illedelmességet és az önállóságot. Volt olyan egykori növendék, aki az emberi kapcsolatok, illetve konfliktushelyzetek kezelésének könynyebbségét is az iskolai katonaerkölcsi nevelésnek tulajdonította. Az alábbi diagram (2. ábra) a kérdésre adott válaszokban található erények megemlítését mutatja be.

A diagram alapján elmondható, hogy a fegyelem, fegyelmezettség kiemelkedik a többi erényes tulajdonság közül. Úgy gondolom, ez teljes mértékben elfogadható, 


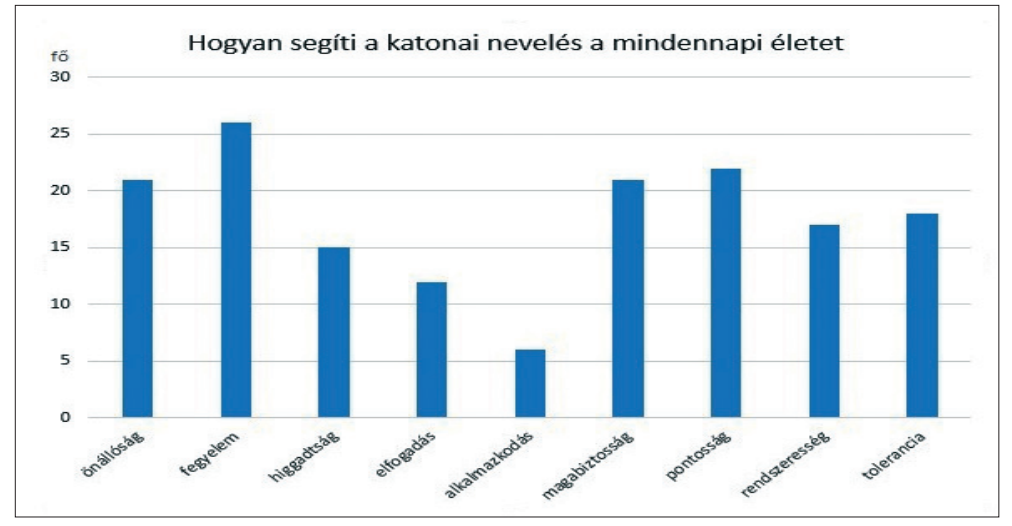

2. ábra.

Hogyan segíti a katonai nevelés a mindennapi életet

(A diagram a szerző saját alkotása)

sôt, elvárható egy honvéd középiskola esetében. Az önállóság, pontosság és magabiztosság szintén rendkívül jól hasznosítható erények mindkét területen, ha a volt növendék karrierjét, elôrejutását vesszük számításba, csak úgy, mint a rendszeresség és rendszeretés. Néhány válaszadó szóbahozta a toleranciára és elfogadásra nevelést, amelyek az emberi kapcsolataiban, illetve azok kialakításában segítették.

"Megtanultam, hogyan lehet összefogni egy csapatot, akiknek a tagjai máshonnan jöttek egy cél érdekében. Nagyban hozzájárult a vezetói képességeim növeléséhez."

Az ötödik kérdés arra irányult, hogy vajon van-e hátránya ennek a kötött formájú nevelési attitúdnek, amit honvédelmi nevelésnek hívunk. Gátolhatja-e a kreativitást, esetleg bizonyos helyzetekben hátrányból indul-e a honvéd középiskolában végzett diák a civil intézményben végzett társukkal szemben? Természetesen itt nem a tanulmányi eredményekre voltam kíváncsi, hanem a katonai jellegú nevelés sajátosságainak esetleges problémákat generáló hatásaira.

A 26 válaszadó közül egy növendék sem adott olyan választ, hogy a honvédelmi nevelés akadályozná vagy hátráltatná bármilyen módon a jelenlegi életét. Számomra ez meglepó eredmény, mert az intézményben dolgozó katonapedagógusként több esetben tapasztalom, hogy a diákjaink nehezen birkóznak meg bizonyos szabályokkal, melyeknek természetesen ésszerú létjogosultságuk van, de a tanuló számára mégis feleslegesnek túnhet. ${ }^{9}$ Bár a kérdés a negatív tapasztalatra irányult, mégis a pozitív tényezók kerültek itt is elótérbe, úgymint a kezdeményezó-képesség fejlesztése, a kreativitás, a küzdőszellem erôsödése és a pozitív értékítélet. Érdekes, hogy a válaszadók fele - még a civil pályát választók is - megemlítette, hogy zavarja óket, ha az utcán valaki hangosan beszél, eldobja a cigaretta csikket stb.

9 Az intézményben olykor tapasztalható, hogy amíg a növendék a KKHKK-ban tanul, nem tud azonosulni, ritkább esetben el sem tudja fogadni az adott szabályt, ezáltal hajlamos kissé eltúlozni a reakcióit a honvédelmi neveléssel kapcsolatban. Aztán amikor az érettségit követóen visszatér hozzánk, egy teljesen más, az iskolára nézve pozitív, nosztalgikus visszaemlékezéssel konstatálja mennyire jó is volt ide járni. 
Az utolsó kérdésben arra kértem az alanyokat, hogy mondjanak 3 erényt, amivel jellemzik a katonaerkölcsi nevelést. Azt gondolom, hogy ha a katonai értékeket akár egy laikustól is megkérdeznénk, a bátorság, becsület és fegyelem szavak biztosan elhangoznának, hiszen ezek egy katona ismérvei a jelenkor társadalmában is. Az eredmény elég egyértelmú és megkérdójelezhetetlen, nem okozott meglepetést számomra, hiszen az imént felsorolt tulajdonságokat már erényként említve a KKHKK volt diákjai is felsorolták. Első helyre a bajtársiasság került, a 26 fóból 25 fő válaszolta. A második helyen a becsületesség áll, melyet 20 fő mondott, és harmadikként érdekes módon nem a bátorság, hanem a fegyelmezettség végzett, melyet 18 fó adott válaszként és csupán a negyedik helyet szerezte meg a bátorság. Ezen felül egy fő a mértékletességet is katonaerkölcsi erényként említette meg (3. ábra).

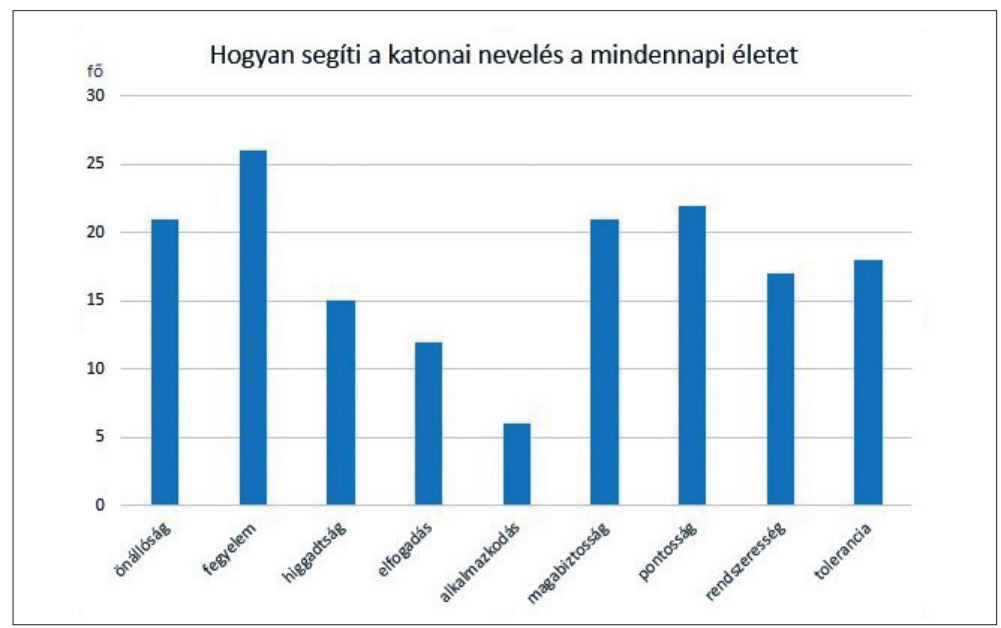

3. ábra.

A katonaetika legfóbb erényei

(A diagram a szerző saját alkotása)

\section{Konklúzió}

Az 1989 utáni magyar társadalomban végbemenô erkölcs-szociológiai változások a honvédségben is jelentkeztek, jobbára az 1999-es NATO csatlakozás után. A keleti vagy másképpen szocialista hadseregek társadalmi legitimáció nélküli berendezkedése folyamatosan átalakult a nyugati típusú, személyi autonómiát megórzố professzionális hadseregképének irányába. A honvédség számára fontossá vált a társadalommal történó kapcsolat fenntartása, akár a személyi állomány feltöltését, akár csupán az anyagi javak beszerzését nézzük. De a sorkatonai szolgálat szüneteltetése és a katonai kollégiumok bezárása mélyítette a katonatársadalom és a polgári társadalom közti rést. Pedig az egymásra utaltság egyértelmú. Az ország szuverenitásának megórzése, határainak védelme a honvédség legfontosabb feladata. Napjainkban, a migrációs válságkezelésben jelentôs részt vállal a honvédség. A déli határszakaszon 2015 óta folyamatosan feladatot ellátó honvédségi alakulatok jelenléte nem 
csupán a migrációs dömping visszaszorításának pozitivitásában mérhető, ${ }^{10}$ hanem abban is, hogy a civil társadalom újra testközelból találkozhat a katonával. Az önkéntes haderőre történő 2004-es átállás óta ez az első közvetlen kapcsolat a két réteg között. A déli megyékben élő emberek a migrációs áradat csökkenésével újra bizalmat szavaztak a magyar katonának, tehát az erkölcsi megítélés pozitív irányba lendült. A pozitív fordulathoz elengedhetetlen a katonák szervezett és fegyelmezett feladat végrehajtása, a katonaerkölcsi normák betartása. A HKK-ban ez a katonaerkölcsi normarendszer megismertetése része a honvédelmi nevelésnek. Hangsúlyozom, hogy vizsgálódásom célja nem egy, az intézmény múködését elemzó vélemény megfogalmazása volt, hanem az intézményben folyó katonaerkölcsi nevelés sikerességének vagy hátrányainak felfedése gyakorlati-tapasztalati módszerek alkalmazásával. A cél az, hogy olyan fiatalok hagyják el az érettségit követóen az intézményt, akik a honvédelem iránt elkötelezettek, hazaszeretőek, függetlenül attól, hogy katonai pályát vagy a civil szférát választják. A katonai pályát választók aránya évról évre növekszik. Amíg a 2014-es évben a végzósök alig 3-5\%-ából lett katona, ez az arány a 2019-es évre 40-45\%-ra növekedett. Több olyan eset is történt, hogy a KKHKK-ban érettségizett fiatal a civil pályára lépve nem találta meg a számítását, ha lehet így fogalmazni, „furcsán érezte magát odakint”, amelynek következményeként szerződéses katonai szolgálatra jelentkezett, és azóta a honvédség legénységi állományú katonája. Az ehhez hasonló példák alapján kimondhatom, hogy a KKHKK a katonai szocializáció elószobája. Az elkészített interjúk alapján úgy gondolom, hogy sikerült reálisan és elfogulatlanul mérnem az intézményben alkalmazott katonaerkölcsi nevelés sikerességét. A végzett növendékek pozitív emlékekkel, örömmel látogatnak el hozzánk, számolnak be mindennapjaikról, sikereikról, vagy esetleges kudarcaikról, legyen szó polgári, vagy katonai életpályáról.

\section{FELHASZNÁLT IRODALOM}

A Kratochvil Károly Honvéd Középiskola és Kollégium házirendje.

http://kratochvil.hu/index.php/dokumentumok (Letöltés ideje: 2019. 10. 15.)

A Kratochvil Károly Honvéd Középiskola és Kollégium évkönyvei (2015-2017).

Beran Ferenc: A keresztény erkölcs alapjai. Budapest, Szent István Társulat, 2001.

Boda Mihály: A katonai vezetés erkölcsi és morális elemei. Hadtudomány, 25. (2015), E-szám.

Katonaetika, tanulmánygyújtemény. Szerk. Molnár Károly ezds. Budapest, Zrínyi Kiadó, 1993.

A KKHKK Pedagógiai Programja. http://kratochvil.hu/index.php/dokumentumok (Letöltés ideje: 2019. 10. 14.)

Martinkó József: Cógerek és katkósok. A katonai középiskolák története. Budapest, Petit Real, 1998.

Rácz Attila: A tömeges irreguláris migrációs válságon innen és túl. Együttérzés, elutasítás, szolidaritás. Rendôrség Tanulmányok, 1. (2018), 3. szám http://www.bmtt.hu/rtt/assets/letolt/rt/201803/02 _racz_attila.pdf (Letöltés ideje: 2020. 02. 07.)

http://www.kratochvil.hu/index.php/iskolankrol (Letöltés ideje: 2019. 10. 14.)

https://magyarnemzet.hu/belfold/ha-szukseges-tobb-ezer-katona-indulhat-a-hatarra-4447592/

(2019. február 14.) (Letöltés ideje: 2019. 10. 16.)

10 Rácz Attila: A tömeges irreguláris migrációs válságon innen és túl. Együttérzés, elutasítás, szolidaritás. Rendörség Tanulmányok, 1. (2018), 3. szám. http://www.bmtt.hu/rtt/assets/letolt /rt/201803/02_racz_attila.pdf (Letöltés ideje: 2020. 02. 07.) 